\title{
Biomechanics and histology of bovine claw suspensory tissue in early acute laminitis
}

\author{
A. M. Danscher, ${ }^{* 1}$ T. H. Toelboell, ${ }^{*}$ and 0 . Wattle $†$ \\ ${ }^{*}$ Department of Large Animal Sciences, Faculty of Life Sciences, University of Copenhagen, 2630 Taastrup, Denmark \\ †Department of Clinical Sciences, Faculty of Veterinary Medicine and Animal Science, Swedish University of Agricultural Sciences, \\ 75007 Uppsala, Sweden
}

\section{ABSTRACT}

Weakening of the suspensory tissue supporting the pedal bone is the central issue in the theory of acute bovine laminitis, but this aspect has never been tested. The objective of this study was to investigate the effect of laminitis on the suspensory tissue. The hypothesis was that clinical and histological signs of acute laminitis are associated with decreased strength of the suspensory tissue of the bovine claw. Nonpregnant dairy heifers (n $=10)$ received oral oligofructose overload $(17 \mathrm{~g} / \mathrm{kg}$ of body weight) and were killed $24(\mathrm{n}=4)$ and $72 \mathrm{~h}(\mathrm{n}=$ $6)$ after overload. Control heifers $(n=6)$ received tap water and were killed at 72 or $96 \mathrm{~h}$. Clinical, orthopedic, and histological examinations were carried out to confirm the occurrence of laminitis. After euthanasia, 2 adjacent tissue samples including the horn wall, lamellar layer, dermis, and pedal bone were cut from the dorso-abaxial aspect of each claw. Tissue samples were kept on ice until mounted on a mechanical testing frame, fixed by horn and bone, and loaded to failure. A stress displacement curve was generated and measurements of physiological support (force needed to displace $1 \mathrm{~mm}$ beyond first resistance) and maximal support (force needed to break the tissue) were recorded. Heifers treated with oligofructose developed clinical signs consistent with ruminal and systemic acidosis after treatment as well as acute laminitis, characterized by weight shifting ( $35 \%$ of observations vs. $6 \%$ in controls), moderate lameness (100 vs. $17 \%$, score of 3 out of 5 at $72 \mathrm{~h}$ ), and reaction to hoof testing (30 and $50 \%$ at 48 and $72 \mathrm{~h}$, respectively, vs. $0 \%$ in controls). Histological examination of claws from heifers killed $72 \mathrm{~h}$ after overload showed changes consistent with acute laminitis, including stretched lamellae, wider basal cells with low chromatin density, and a thick, wavy, and blurry appearance of the basement membrane. Biomechani-

\footnotetext{
Received January 16, 2009.

Accepted October 1, 2009.

${ }^{1}$ Corresponding author: amd@life.ku.dk
}

cal results showed no effect of oligofructose overload on physiological support of the suspensory tissue at 24 and $72 \mathrm{~h}$ after overload; in contrast, overload increased maximal support of the tissue $72 \mathrm{~h}$ after overload. Herd of origin and location of the sample had large effects on both physiological support and maximal support (herd $=547 \mathrm{~N} / \mathrm{cm}^{2}$; location $=531 \mathrm{~N} / \mathrm{cm}^{2}$ ) of claw suspensory tissue (herd $=260 \mathrm{~N} / \mathrm{cm}^{2}$; location $=327 \mathrm{~N} / \mathrm{cm}^{2}$ ). Despite clinical and histological signs of laminitis, no weakening of the suspensory tissue of the bovine claw was detected at 24 and $72 \mathrm{~h}$ after oligofructose overload. Herd factors appeared to be important for claw suspensory tissue strength.

Key words: biomechanics, histology, claw suspensory tissue, bovine laminitis

\section{INTRODUCTION}

Claw lesions and lameness are observed commonly in dairy herds (Cook, 2003; Capion et al., 2008; Cramer et al., 2008) and affect both the welfare and productivity of the animals (Sprecher et al., 1997; Green et al., 2002; O'Callaghan et al., 2003). The group of claw lesions relating to the claw horn is collectively known as claw horn disruptions, some of which are believed to be caused by subclinical laminitis. Epidemiological and experimental studies have associated a variety of different factors of subclinical laminitis (Bergsten, 1994; Webster, 2001; Cook et al., 2004), but causal relationships and pathogenesis have not been fully elucidated. Intensive feeding, causing subacute ruminal acidosis, in high producing cattle was one of the factors associated with subclinical laminitis (Peterse, 1979; Livesey et al., 1998; Donovan et al., 2004). The theory is that subacute ruminal acidosis can damage the rumen epithelia and allow toxic substances from the ruminal contents to pass directly into the bloodstream, affecting the claws. In the claws, these toxic substances cause a weakening of the tissue suspending the pedal bone in the claw capsule, either by direct toxic effects or by impeding the blood supply. Because of this weakening, the weight of the cow results in the pedal bone being 
pushed downwards, crushing the soft tissue situated between the bone and the horn capsule. This results in hemorrhages and further circulatory changes and, in turn, in impaired horn production and lameness (Mulling and Lischer, 2002). This theory is a direct parallel to the theory of acute laminitis pathogenesis. Acute laminitis can develop after a sudden ingestion of large amounts of carbohydrate, causing acute, severe ruminal acidosis and resulting in acute lameness accompanied with general signs of disease. Acute clinical laminitis developing after carbohydrate engorgement was known for centuries but, despite intensive research, the exact pathogenesis remains unclear (Bergsten and Mulling, 2004). Nevertheless, one of the main hypotheses in the theory of acute bovine laminitis, the weakening of the suspensory tissue, has never been tested. The hypothesis of this study was that clinical and histological signs of acute laminitis 24 and $72 \mathrm{~h}$ after oligofructose overload are associated with decreased strength of the suspensory tissue of the claw. The objective of this study was to investigate the effect of laminitis on the suspensory tissue.

\section{MATERIALS AND METHODS}

\section{Animals}

Danish Holstein heifers or crosses (Jerseys or Red Danish $\times$ Holstein $\mathrm{n}=16$, aged 13-23 mo, BW $=357$ $515 \mathrm{~kg}$ ) were used. All heifers were clinically healthy and with no history of severe systemic disease or claw lesions. The heifers originated from 2 different herds; in herd $\mathrm{A}(\mathrm{n}=5)$, heifers were housed in tie-stalls on a straw-bedded concrete floor; in herd B $(\mathrm{n}=11)$, heifers were housed in free stalls with cubicles and solid rubber floors. During the experiment, the heifers were housed in tie-stalls on a concrete floor bedded with 3 to $4 \mathrm{~cm}$ of wood shavings and fed grass hay ad libitum. The heifers were acclimated to the tie-stall for $1 \mathrm{wk}$ and accustomed to the feed for at least 4 wk before the trial. During the acclimation, heifers were trained to be handled, including having their front feet lifted and being led by hand in walking and trotting. Indwelling jugular catheters (Milacath Extended Use, 14G, $9 \mathrm{~cm}$, Mila International Inc., Erlanger, KY) were placed on the first day of the trial.

\section{Experimental Treatment and Design}

Oligofructose (Beneo P95, Orafti Active Food Ingredients, Tienen, Belgium) dissolved in warm water was given by stomach tube to 10 heifers at a dose of $17 \mathrm{~g}$ of oligofructose $/ \mathrm{kg}$ of $\mathrm{BW}$ in $2 \mathrm{~L} / 100 \mathrm{~kg}$ of $\mathrm{BW}$ of water. A priming dose of $5 \%$ of the main dose was given with
$250 \mathrm{~g}$ of standard dairy cow concentrate (Danko C11, DLG, Copenhagen, Denmark) twice daily for $3 \mathrm{~d}$ before the trial (Thoefner et al., 2004). Control heifers $(n=6)$ were given only concentrate and were tubed with water. Of the heifers given oligofructose, 4 were killed after $24 \mathrm{~h}(\mathbf{O F} 24)$ and 6 after $72 \mathrm{~h}$ (OF72). The 6 control heifers were killed after 72 or $96 \mathrm{~h}$. The experiment was carried out as a randomized complete block design with 4 blocks of 4 heifers. Within blocks, heifers were allocated randomly to treatment groups while ensuring that the 2 herds were equally represented in the treatment groups.

\section{Model Validation}

General clinical examinations were performed at 6- to 12-h intervals from oligofructose overload until euthanasia. Weight shifting was defined as a shifting of weight laterally from one leg to another in a monotonous manner, judged not caused by flies or other external influences. Weight shifting was noted if observed during the examination periods at 6 - to 12 -h intervals.

Locomotion scoring was performed at 24 -h intervals according to Sprecher et al. (1997). Using the scale, 1 was normal, stands and walks with level-back posture; 2 was mildly lame, stands with level back, walks with arched back, gait remains normal; 3 was moderately lame, stands and walks with arched back, short-striding with 1 or more limbs; 4 was lame, always arched back, favors 1 or more limbs; and 5 was severely lame, inability or extreme reluctance to bear weight on 1 or more limbs. Shortening of the stride and other obvious signs of lameness overruled back posture characteristics.

Hoof-testing was performed at 24-h intervals on all 4 front claws. One person lifted the leg while another applied a large standard hoof-tester over the axial solebulb junction and the central part of the dorso-abaxial claw wall. The pressure applied was just enough to visually appreciate the sole horn yield, and the reaction was assessed both as fasciculation in the triceps muscle and as attempts to withdraw the leg. Reaction to hoof testing was subjectively graded as $0=$ no reaction or 1 $=\mathrm{a}$ positive reaction. If necessary, the procedure was repeated to distinguish pain from nonspecific reactions.

\section{Additional Treatment}

All treated heifers received supportive i.v. fluid therapy. One heifer (OF24) displayed hyperventilation and tachycardia and was treated with $30 \mathrm{mg}$ of buthorphanol $(0.07 \mathrm{mg} / \mathrm{kg}$ of BW; Torbugesic vet, ScanVet Animal Health, Fredensborg, Denmark). 


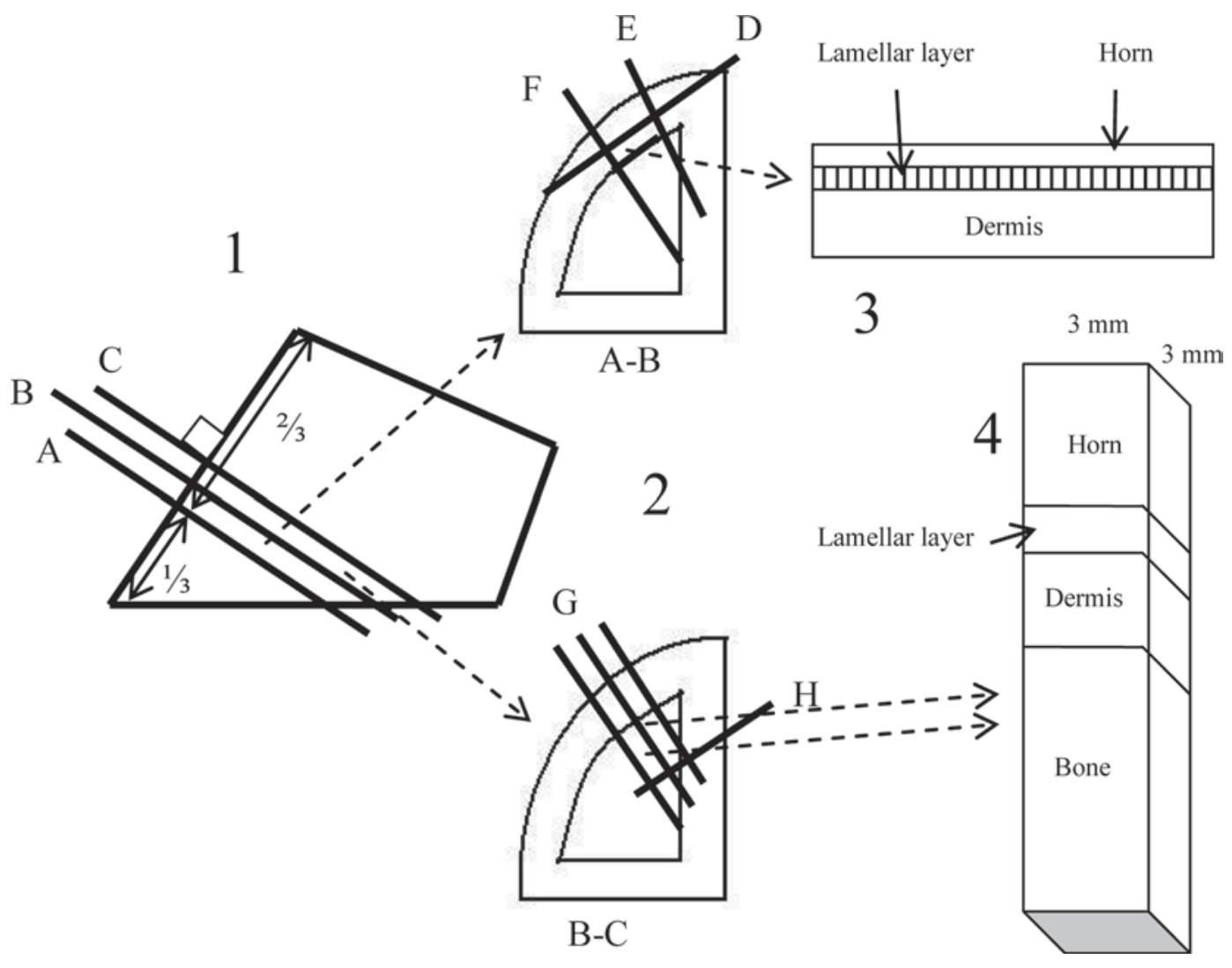

Figure 1. Sampling of claw tissue. In each claw (1), 3 transverse cuts (A, B, and C) were made perpendicular to the dorsal claw wall. Cut A was made one-third of the distance from the tip of the toe to the junction between the horn capsule and the skin, cut $\mathrm{B}$ was 5 mm proximal to $\mathrm{A}$, and cut $\mathrm{C}$ was $3 \mathrm{~mm}$ proximal to $\mathrm{B}$. These 3 cuts resulted in 2 slices of tissue, A-B and B-C (2). On slice A-B, the horn was removed down to $2 \mathrm{~mm}$ from the lamellae (D). In the dorso-abaxial wall, a cut (E) was placed $0.5 \mathrm{~cm}$ abaxial to the crest of the dorsal claw wall and another cut (F) 10 to $12 \mathrm{~mm}$ abaxial to E. The isolated tissue sample was separated from the underlying bone by a scalpel incision through the dermis as close to the pedal bone as possible. This sample (3) was processed for histological examination. In slice B-C, 3 parallel cuts (3 mm apart) were made perpendicular to the most level surface of the dorso-abaxial claw wall $(\mathrm{G})$. These cuts produced 2 adjacent rods of tissue consisting of horn, lamellar layer, dermis, and bone. The rods were separated from the rest of the slice by a cut perpendicular to the 3 cuts and through the bone $(\mathrm{H})$. These 2 samples were obtained for mechanical testing (4).

\section{Tissue Sampling}

Immediately after euthanasia by captive bolt and exsanguination, the feet were removed at the level of the fetlock joint. The medial and lateral claws were separated. Tissue samples for histological examination and mechanical testing from all 8 claws were subsequently cut free with a band saw (Figure 1).

\section{Histopathology}

Samples were fixed for $24 \mathrm{~h}$ in $4 \%$ neutral buffered formaldehyde (in 4 heifers, $4 \%$ paraformaldehyde was used instead). Following fixation, the tissue samples were immersed in $70 \%$ ethanol for a maximum of 7 d. The samples were then dehydrated through graded concentrations of ethanol and xylene and embedded in paraffin wax (Bancroft and Stevens, 1996). Tissue sections of 3 to $5 \mu \mathrm{m}$ were stained with hematoxylin and eosin and periodic acid-Schiff (Bancroft and Stevens, 1996).

The histological sections were then coded by an independent person. Sections were subsequently examined under a light microscope at 4, 10, and 40 times magnification by 2 independent researchers after a short joint introduction. Several histological characteristics related to acute laminitis were subjectively scored using a scale ranging from 0 to $6(0=$ no changes, $2=$ mild changes, $4=$ moderate changes, and $6=$ severe changes $)$. The characteristics assessed were stretching of lamellae, white blood cells in blood vessels, white blood cells in tissues, hyperemia, hemorrhage, intracellular edema, basement membrane detachment, basal cell shape, necrosis, number of suprabasal cell layers, and basal cell chromatin density ( 0 for heterochromatin and 6 for euchromatin; Thoefner et al., 2005). In addition, changes in the basement membrane toward a thicker, 


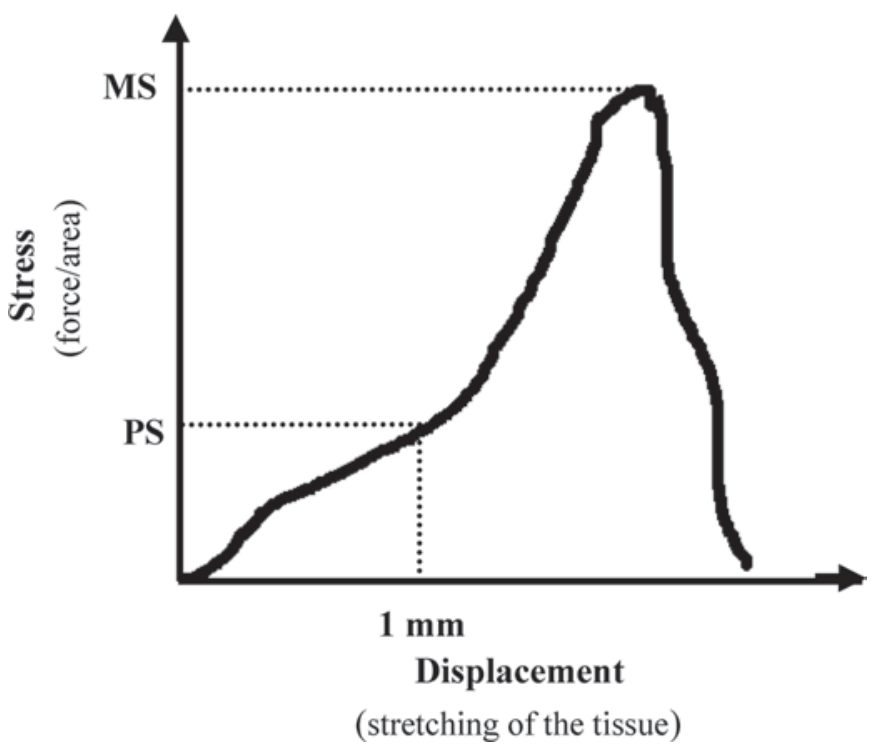

Figure 2. Stress displacement curve generated by fixing claw tissue samples by horn and bone in a mechanical testing frame and loading to failure at a constant displacement rate of $2.0 \mathrm{~mm} / \mathrm{s}$. Stress displacement curves were generated for each sample, and maximal support (MS) and physiological support (PS) were recorded.

wavy, and blurred appearance were noted. A total of 128 histological sections were examined (48 control, 48 OF72, and 32 OF24 sections).

\section{Biomechanical Testing}

The most dorsal tissue samples were marked and samples were kept in plastic containers on ice until testing. Mechanical testing was performed within 5 to $8 \mathrm{~h}$ after euthanasia. The dimensions of the samples were measured using digital calipers (Limit, Teng Tools International, Alingsås, Sweden) and cross-sectional areas were calculated. Each sample was mounted on an Instron 5564 mechanical testing frame (Instron, High Wycombe, UK), fixed by the horn and bone, and loaded to failure at a constant displacement rate of 2.0 $\mathrm{mm} / \mathrm{s}$. After failure, samples were assessed visually and the primary anatomical site of tissue separation was noted for each sample. A curve graph was generated depicting displacement of horn relative to bone against stress (Figure 2). To correct for variations in the fixing of samples, the first measurements above $1 \mathrm{~N} / \mathrm{cm}^{2}$ were used as baselines from which all other measurements were calculated.

The following variables were recorded from the stress displacement curve (Figure 2): physiological support (PS), defined as the stress needed to displace the horn $1 \mathrm{~mm}$ relative to the bone, and maximal support (MS), defined as the maximal stress needed to break the tis- sue. Both PS and MS were used as outcome variables in the statistical analyses.

\section{Statistical Methods}

Histology. The nonparametric Kruskal-Wallis test (Proc NPAR1WAY, Wilcoxon; SAS, version 9.1, SAS Institute, Cary, NC) was used to analyze whether the distribution of histological scores was dependent on the claw or leg from which the samples originated. A Kruskal-Wallis test on a rounded mean score from each heifer was used to analyze whether the distribution of histological scores differed between the control group and the 2 treatment groups (OF24 and OF72), and it was used to determine whether the location of separation differed between the control group and the 2 treatment groups. $P$-values $<0.05$ were considered significant.

Mechanical Testing. After graphic validation of the model, the square root-transformed response variables, PS and MS, were analyzed separately by a random effects model (Proc MIXED with Satterthwaite's approximated $F$-tests; SAS, version 9.1). Explanatory variables included in the full model were treatment group, herd of origin, age, BW, leg (front or hind), claw (lateral or medial), and location of sample [dorsal or palmar (plantar)]. Interactions between herd and treatment as well as all interactions between leg, claw, and location of the sample were included in the full model. Heifer identity and block were included as random effects. Model reduction was performed by stepwise backward elimination, removing the least significant variable or interaction until all remaining terms were significant at $P<0.05$.

\section{Ethical Considerations}

The experiment was planned and performed in a manner aiming to prevent any unnecessary pain and discomfort in the animals. The experiment was ethically approved by the Danish Animal Experiments Inspectorate (Copenhagen, Denmark, file no. 2006/561-1132) before initiation.

\section{RESULTS}

\section{Model Validation}

All heifers receiving oligofructose overload developed reduced ruminal contractions, dehydration, anorexia, depression, and profuse watery diarrhea (Danscher et al., 2009b). These clinical signs were considered consistent with acute ruminal and systemic acidosis. 
Weight shifting was observed in 9 of 10 heifers receiving oligofructose overload and in 30 of the 86 examination periods (35\%). Weight shifting was observed from 6 to $72 \mathrm{~h}$ after overload, but most observations were between 6 and $42 \mathrm{~h}$ (Figure 3 ). Locomotion scoring at $24 \mathrm{~h}$ after overload showed that 2 of 4 OF24 heifers and 1 of 6 OF72 heifers were mildly or moderately lame (score $=2$ or 3 ; Figure 3 ). At $72 \mathrm{~h}$ after overload, all 6 OF72 heifers were moderately lame (score $=3$ ). Hoof testing resulted in an increased number of positive reactions at $48 \mathrm{~h}(30 \%)$ and $72 \mathrm{~h}(50 \%)$ after overload (Table 1).

Control heifers showed no signs of systemic disease, no change in locomotion score, and no reactions to hoof testing during the experiment. Weight shifting was observed in 4 out of 70 examination periods $(6 \%)$.

\section{Histopathology}

Both observers (1 and 2) agreed that claw sections from OF72 heifers had wider basal cells (data not shown) and lower chromatin density of the basal cells (data not shown) compared with control heifers $(P<$ 0.05; Figure 4). In addition, both observers detected a greater proportion of stretched lamellae (data not shown) as well as a thick, wavy, and blurry appearance of the basement membrane and increased vacuolation of the basal cell cytoplasm (intracellular edema) in

A

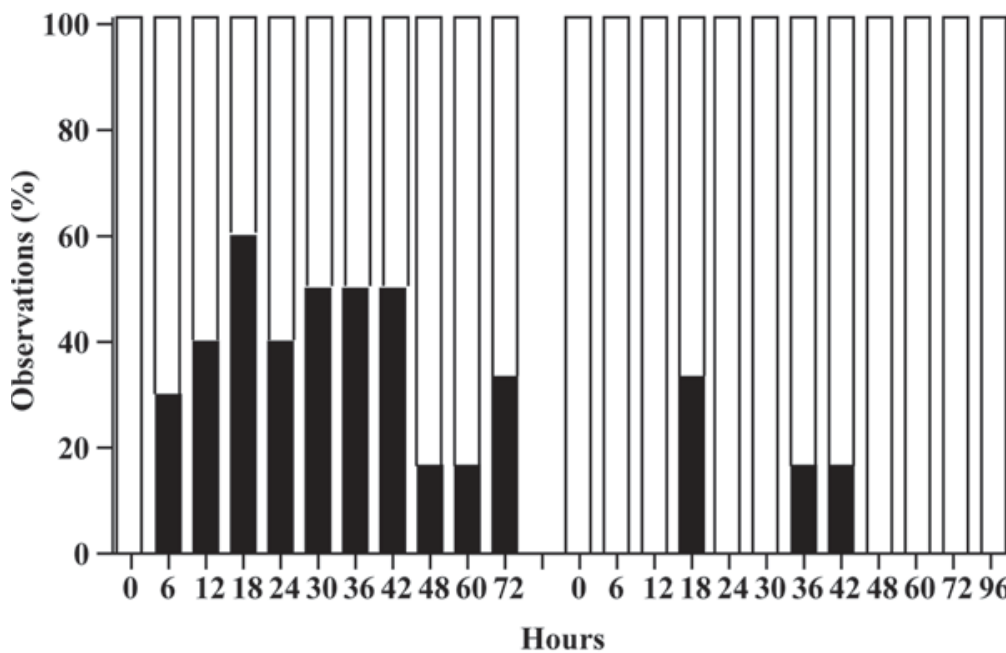

\section{Weight shifting}
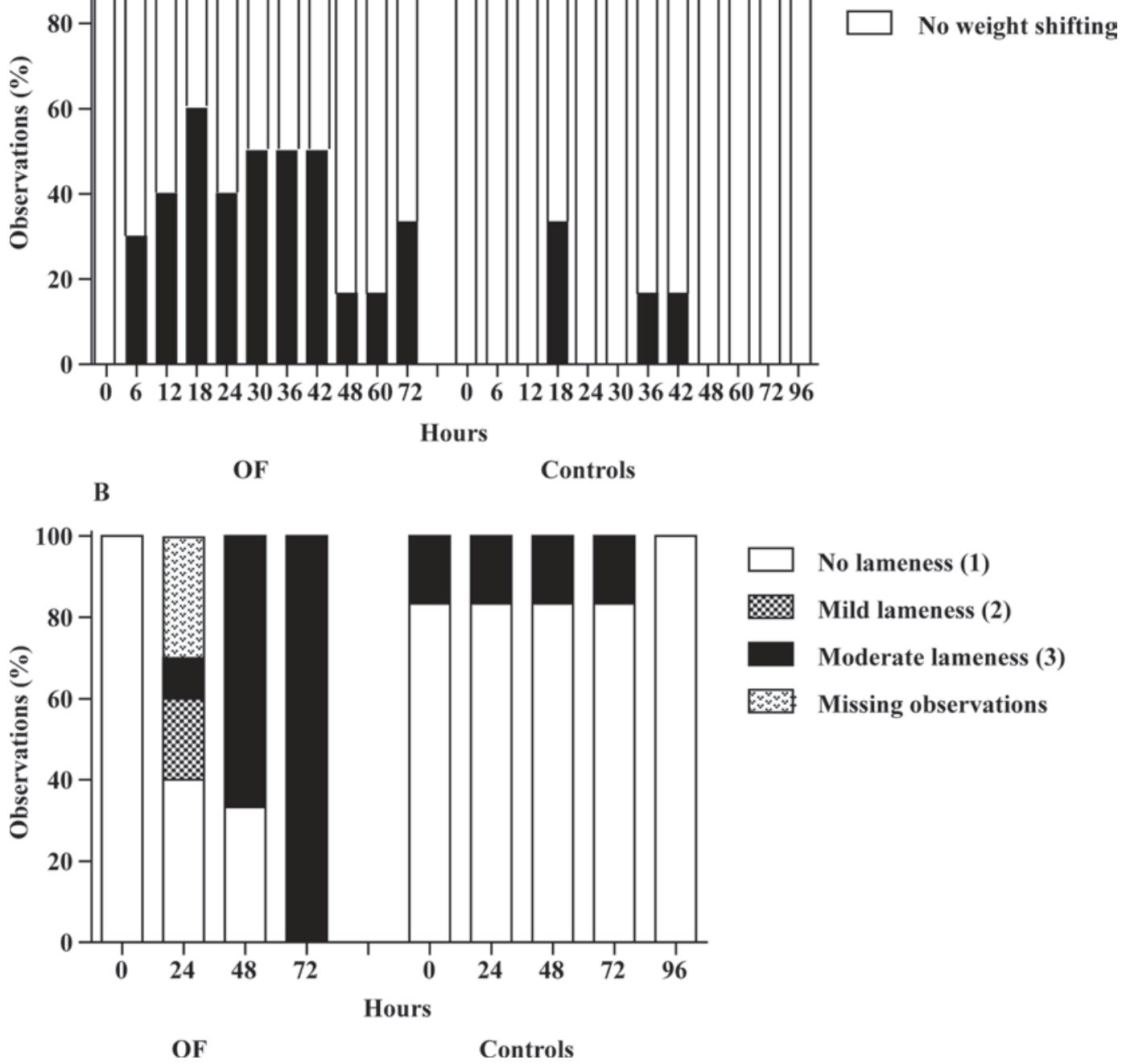

Figure 3. A) Weight shifting and B) locomotion scores of heifers receiving oligofructose (OF) overload $(17 \mathrm{~g} / \mathrm{kg}$ of $\mathrm{BW})$ at $0 \mathrm{~h}$ and in control heifers receiving tap water at $0 \mathrm{~h}$. In 3 heifers, it was not possible to perform locomotion scoring at $24 \mathrm{~h}$ because of ataxia (3 missing observations). One control heifer showed consistent moderate lameness during the trial. 
Table 1. Number of claws with positive reactions to hoof testing in heifers receiving oligofructose overload ${ }^{1}$ at $0 \mathrm{~h}$ and in control heifers receiving tap water at $0 \mathrm{~h}^{2}$

\begin{tabular}{|c|c|c|c|c|c|c|c|}
\hline \multirow[b]{2}{*}{ Time $(\mathrm{h})$} & \multicolumn{5}{|c|}{ Oligofructose overload heifers ${ }^{3}$} & \multicolumn{2}{|c|}{ Control heifers } \\
\hline & LFL & LFM & RFM & RFL & Total claws tested & All claws & Total claws tested \\
\hline 0 & 0 & 1 & 1 & 1 & 40 & 0 & 24 \\
\hline 24 & 0 & 0 & 0 & 0 & 32 & 1 & 23 \\
\hline 48 & 3 & 1 & 1 & 1 & 20 & 0 & 16 \\
\hline 72 & 4 & 1 & 4 & 3 & 24 & 0 & 22 \\
\hline
\end{tabular}

OF72 sections compared with control sections (Figure 4). Ambiguity over the degree of stretched lamella, changes in the basement membrane, and development of intracellular edema arose from inconsistencies between the observers regarding scoring of the severity of the lesions at OF72 (Table 2). In addition, only observer 2 observed an increased number of white blood cells in blood vessels $24 \mathrm{~h}$ after overload $(P=0.014)$. Occasional pycnotic cells and mitotic figures were seen in both control and treated animals (data not shown). No significant differences were found between control and treated heifers regarding occurrence of hyperemia, hemorrhage, necrosis, white blood cells in dermis, number of suprabasal cell layers, and detachment of the basement membrane (data not shown). Signs of thrombosis were not observed. There was no general effect of claw and leg on the observed histopathology characteristics in the oligofructose-treated animals. In the OF72 heifers separately, observer 2 found a lower level of stretched lamellae in the medial front claws than in the other claws $(P=0.0495$; data not shown).

\section{Biomechanical Testing}

Physiological support was not affected by oligofructose overload (Figure 5A). However, the herd of origin of the heifers and the location of the sample in the claw had major effects on PS (Table 3; Figure 5B). Samples from herd B had higher PS values than samples from herd A, and dorsal samples had higher PS values than palmar (plantar) samples. There was an effect of leg and claw on the results (Table 3 ).

Maximal support was higher in samples from OF72 heifers than in claws from control heifers, and effects of herd of origin, location, claw, and leg were observed (Table 4). Maximal support was higher in samples from herd $\mathrm{B}$ relative to herd $\mathrm{A}$, in dorsal samples relative to palmar (plantar) samples, in medial claw samples relative to lateral claw samples, and in hind claw samples relative to front claw samples (Table 4).
The primary anatomical site of tissue separation in the control samples was in the dermis (79\%), the dermo-epidermal junction (17\%), or over the bone or horn $(2 \%)$. In the OF24 samples, primary separation was in the dermis $(68 \%)$ or the dermo-epidermal junction $(32 \%)$. In the OF72 samples, primary separation was in the dermis (64\%), the dermo-epidermal junction $(28 \%)$, or over the bone or horn $(8 \%)$. The differences were not significant when analyzed at cow level.

\section{DISCUSSION}

\section{Biomechanical Testing}

The main finding was that despite clinical and histological signs of laminitis, oligofructose overload did not cause decreased strength of the suspensory tissue of the claw at 24 and $72 \mathrm{~h}$ after overload. Thus, the initial hypothesis could not be supported by the results. Nevertheless, it is possible that weakening of the suspensory tissue could occur later than $72 \mathrm{~h}$.

Mechanical testing of claw suspensory tissue is complicated and presents several challenges. The composition of hard and soft tissues makes cutting uniform samples difficult, and the dimensions of the actual suspensory tissue tested were difficult to measure exactly. The samples were cut perpendicular to the dorsal claw wall and, consequently, the direction of the force applied was perpendicular to the plane of the dermo-epidermal junction. The direction of the test force roughly corresponded to the direction of the collagen fibers of the distal part of dermal suspensory tissue (Maierl, 2004). Intuitively, it would correspond to the direction of the force exerted in the propulsion phase of the stride. Yet, the forces exerted in the standing animal would have a steeper angle to the claw wall. Testing the ability of the tissue to withstand forces in this direction could perhaps provide more information about the suspension of the pedal bone in housed cattle but would have complicated measuring the samples and standard- 
Table 2. Probability values obtained from the nonparametric Kruskal-Wallis test for difference between histological characteristics of control heifers receiving no oligofructose and of heifers killed 24 (OF24) or $72 \mathrm{~h}$ (OF72) after oligofructose overload ${ }^{1}$

\begin{tabular}{llllll}
\hline & \multicolumn{2}{c}{ Observer 1} & & \multicolumn{2}{c}{ Observer 2 } \\
\cline { 2 - 3 } \cline { 5 - 6 } Characteristic & \multirow{2}{*}{ OF24 } & OF72 & & \multirow{2}{*}{ OF24 } & OF72 \\
\hline Wider basal cells & 0.17 & 0.046 & & 0.79 & 0.005 \\
Low chromatin density & 0.15 & 0.029 & & 0.22 & 0.019 \\
Stretched lamellae & 1 & 0.13 & & 0.19 & 0.009 \\
Basement membrane changes & 0.91 & 0.17 & & 0.45 & 0.019 \\
Intracellular edema & 0.88 & 0.067 & & 1 & 0.045 \\
White blood cells in vessels & 0.76 & 0.52 & & 0.014 & 0.24 \\
\hline
\end{tabular}

${ }^{1}$ Results are presented for individual observers. Oligofructose overload $=17 \mathrm{~g} / \mathrm{kg}$ of BW.

izing the force exerted. These methodology problems contributed with excess variance but were unlikely to influence the treatment groups more or less compared with the controls. Therefore, because of significant effects of herd of origin and location of tissue samples and because of increased MS levels detected, this goes against a suggestion that problems with the methodology could have hidden an actual weakening effect of the treatment. Displacement of the pedal bone in cows with sole ulcers was assessed directly by Lischer et al. (2002) using transverse sections of the claw at the level of the tuberculum flexorium. This or other direct methods to

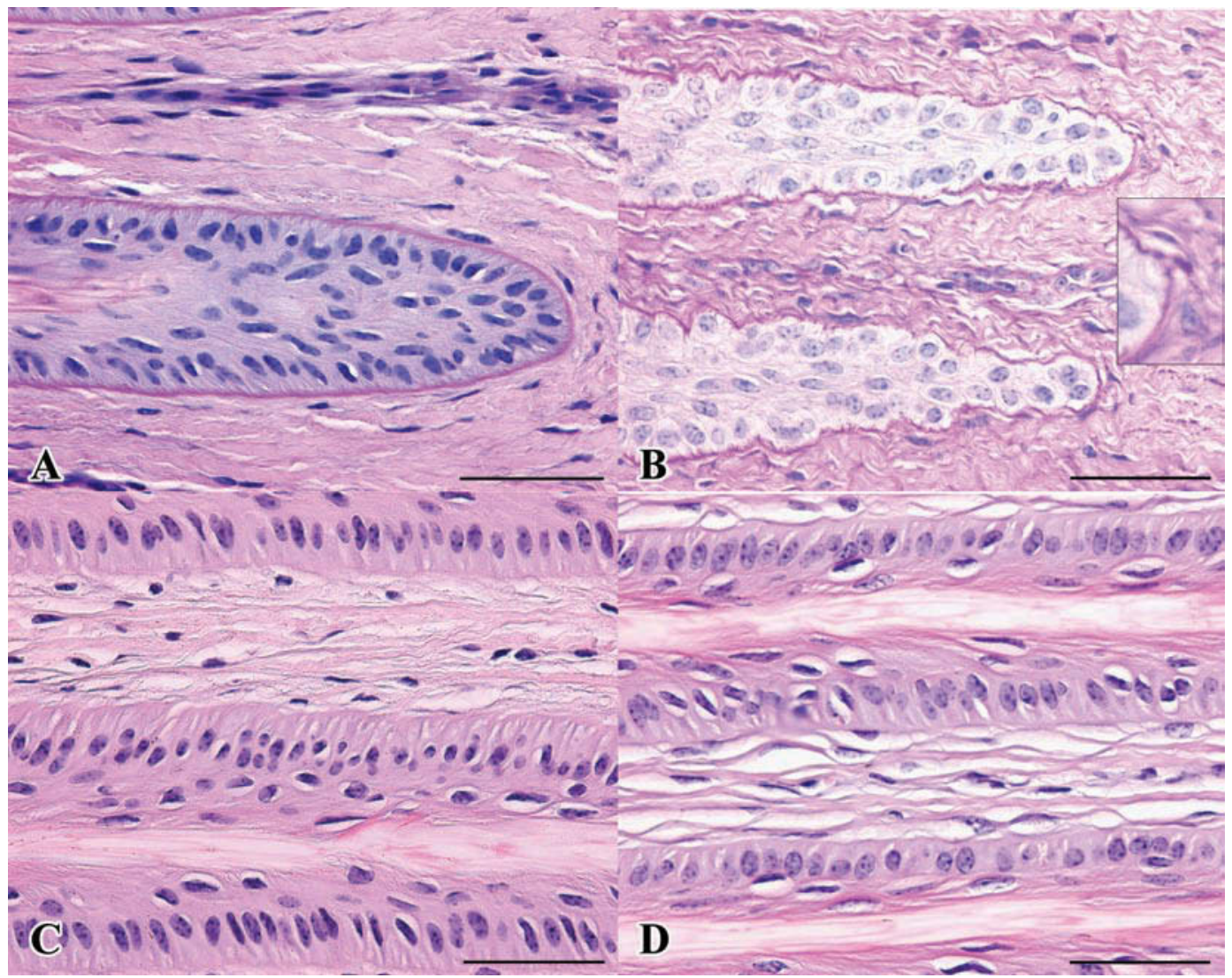

Figure 4. Transverse sections of tissue from the dorso-abaxial claw wall; right side is toward the pedal bone. Scale bars are $50 \mu \mathrm{m}$. A, B) Sections of innermost tips of the lamellar layer stained with periodic acid-Schiff. C, D) Sections of the mid lamellar layer (halfway between the claw wall and the innermost tips) stained with hematoxylin and eosin. A) Control heifer, right hind lateral claw. Well-defined basement membrane, columnar basal cells with dark-stained nuclei (heterochromatin). B) Heifer killed $72 \mathrm{~h}$ after oligofructose overload (17 g/kg of BW), right hind lateral claw. Stretched lamellae, 1 to 2 cell layers thick, blurry and wavy basement membrane, cuboidal basal cells with rounded, lightstained nuclei (euchromatin). Insertion shows detached basement membrane at the tip of the upper lamella. C) Control heifer, left front medial claw. Columnar basal cells with dark-stained nuclei. D) Heifer killed $72 \mathrm{~h}$ after oligofructose overload, left front medial claw. Cuboidal basal cells with rounded, light-stained nuclei positioned closer to the basal membrane. Color version available in the online PDF. 
Table 3. Effects on physiological support of claw suspensory tissue expressed as differences between least squares means from the random effects model transformed back to the original scale $(\mathrm{n}=225)$

\begin{tabular}{llcc}
\hline Effect & Calculation & Difference $\left(\mathrm{N} / \mathrm{cm}^{2}\right)$ & $P$-value \\
\hline Herd & B - A & 260 & $<0.0001$ \\
Leg & Hind - front & 52 & 0.033 \\
Claw & Medial - lateral & 57 & 0.019 \\
Location & Dorsal - palmar (plantar) & 327 & $<0.0001$ \\
\hline
\end{tabular}

assess pedal bone displacement could be useful in studies of laminitis pathophysiology.

The general theory that suspensory tissue weakening is a central feature of laminitis pathogenesis could not be supported by this study. However, the results supported previous studies that showed suspensory tissue strength was affected by housing but not by diet (Tarlton et al., 2002; Knott et al., 2007). Also, this study supports the view that diet may play a less important role in the development of bovine laminitis and lameness than previously thought (Webster et al., 2005). The histological changes observed were mild, and it is possible that one incidence of acute oligofructose overload in cattle was too mild a laminitis model to induce weakening of the tissue. Perhaps repeated bouts of acute or subacute acidosis or long-term repeated loading of the affected tissue is required to weaken the tissue.

The histological changes in the lamellae observed despite the unaffected tissue strength at 24 and $72 \mathrm{~h}$ may be the only effect on the tissue in this laminitis model or may precede a later weakening of the tissue. The claw pain and lameness observed could be caused by local production of pain-eliciting factors in the compromised claw tissue despite the absence of evidence of inflammation. Also, an aseptic polysynovitis was observed in the oligofructose-treated animals (Danscher et al., 2009b) that most likely contributed to claw pain and lameness.

The small increase in MS after oligofructose overload was in direct contradiction to the common perceptions of laminitis pathogenesis (Bergsten and Mulling, 2004) and was difficult to explain. Maximal suspensory tissue strength may be of less importance in the living animal.

The large effect of herd on PS and MS can be attributed to several long-term factors affecting tissue strength. This study was not set up to detect or differentiate between such factors, so it can only be speculated which are important. Differences in the amount of daily exercise in the 2 herds may be vital because exercise is known to influence biomechanical properties of connective tissue (Dowling and Dart, 2005). In addition, floor properties, management, genetics, and previous nutrition and disease are known risk factors for subclinical laminitis (Bergsten, 1994; Webster, 2001;
Cook et al., 2004) and may have a long-term influence on tissue strength.

The more dorsal of the 2 tissue samples were stronger than the more abaxial despite the fact that the
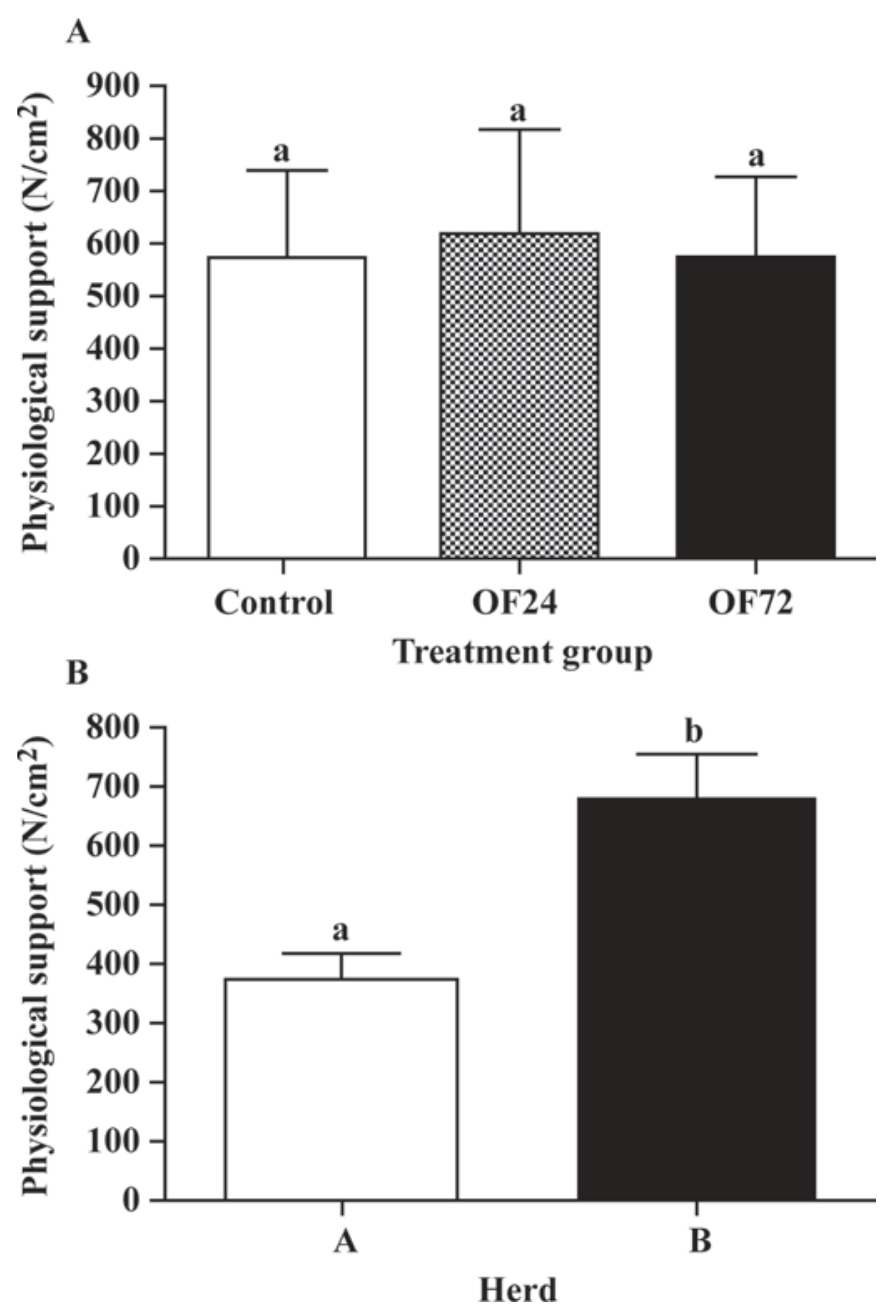

Figure 5. A) Means $( \pm \mathrm{SD})$ of physiological support of claw suspensory tissue samples from all 8 claws of 6 control heifers, 4 heifers killed $24 \mathrm{~h}$ after oligofructose overload (17 g/ $\mathrm{kg}$ of BW; OF24), and 6 heifers killed $72 \mathrm{~h}$ after oligofructose overload (OF72). All groups included heifers from both herds A and B. B) Physiological support of claw suspensory tissue samples from all 8 claws of 5 heifers originating from herd A and 9 heifers originating from herd B. Both herd groups included control heifers and OF 24 and OF 72 heifers $(\mathrm{n}=225)$. Bars with different superscripts differ $(P<0.0001)$. 
Table 4. Effects on maximal support of claw suspensory tissue expressed as differences between least squares means from the random effects model transformed back to the original scale $(\mathrm{n}=243)$

\begin{tabular}{llcc}
\hline Effect & Calculation $^{1}$ & ${\text { Difference }\left(\mathrm{N} / \mathrm{cm}^{2}\right)}^{2}$ & $P$-value \\
\hline Herd & B - A & 547 & $<0.0001$ \\
Leg & Hind - front & 335 & $<0.0001$ \\
Claw & Medial - lateral & 106 & 0.0039 \\
Location & Dorsal - palmar (plantar) & 531 & $<0.0001$ \\
Treatment & Control - OF24 & -60 & 0.17 \\
& Control - OF72 & -145 & 0.0004 \\
\hline
\end{tabular}

${ }^{1}$ Nonpregnant dairy heifers received oral oligofructose overload $(17 \mathrm{~g} / \mathrm{kg}$ of BW) and were killed at $24 \mathrm{~h}$ (OF24) or $72 \mathrm{~h}$ (OF72) after overload. Control heifers received tap water and were killed at 72 or $96 \mathrm{~h}$.

samples were small (approximately $3 \times 3 \mathrm{~mm}$ ) and situated next to each other. Maierl et al. (2002) showed abaxial samples to be stronger than dorsal, but these samples were situated further apart than in the present study. Larger blood vessels were visible in some abaxial samples; this may have contributed to lower tissue strength. Change in dimensions and angle of the lamellae from dorsal to abaxial may influence the biomechanical properties (Furst, 1992). The results stress the importance of standardized sampling and, if possible, collecting several samples from each claw when performing biomechanical studies. Further studies are needed regarding the general variance of tissue strength between different locations on the claw.

The suspensory tissue of the hind claws was stronger than that of the front, and the medial claws were stronger than the lateral. Previous studies showed no difference between legs or claws (Maierl et al., 2002). The hind legs carried $44 \%$ of the BW (Chapinal, 2008), but because they are used to propel the body forward they may need a stronger suspensory apparatus.

Laminitis may result in decreased strength of either or both the dermal and epidermal layers of the suspensory apparatus. The term laminitis implies that the lamellae are the primary target site; changes in lamellar histology were observed both in the present study and previously (Nilsson, 1963; Thoefner et al., 2005). Tarlton et al. (2002) and Knott et al. (2007) showed changes in composition and metabolism of the dermis in relation to parturition, lactation, and cubicle housing coincident with changes of lamellar histology, decreased tissue strength, and solar lesions, indicating that the dermal layer might also be involved in the pathogenesis of bovine laminitis. In the present study, the anatomical site of tissue separation did not differ between treatment groups when corrected for dependence of samples from the same heifer.

\section{Model Validation}

The present study confirmed that oligofructose overload resulted in clinical laminitis with mild histological changes, supporting earlier reports (Thoefner et al., 2004, 2005; Danscher et al., 2009a). The present study adds the strength of a study design with the blind scoring of all histological sections by 2 independent observers. The 2 observers agreed upon the overall conclusions, but disagreement between the observers was observed concerning the grading of histopathological changes. Problems with interobserver agreement in histopathologic grading systems is a well-known phenomenon (Cross, 1998).

Most of the 48 examined histological sections from OF72 heifers showed histological changes in more than 1 of the described categories, but in a few, no histological changes were observed. Previous studies on experimentally induced laminitis in cattle and horses reported that both clinical signs and histological appearance of the lamellae varied within and between individual animals, and some treated animals did not develop laminitis (Obel, 1948; Nilsson, 1963; Thoefner et al., 2005). In addition, a small number of sections from control heifers showed some histological changes associated with laminitis; however, seldom did this occur in more than 1 of the observed categories.

\section{CONCLUSIONS}

Oligofructose overload induced clinical and histological signs of acute laminitis in dairy heifers, but overload was not associated with decreased strength of the suspensory tissue supporting the pedal bone in the claw capsule at 24 and $72 \mathrm{~h}$ after overload. Herd of origin as well as the location of the sample had an effect on tissue strength. Further investigations of claw suspensory tissue strength should include standardized sampling and controlled herd factors.

\section{ACKNOWLEDGMENTS}

This study was a part of the Sund Klov (Healthy Claw) project supported by the Danish Milk Levy Fund (Danish Dairy Board, Aarhus, Denmark). Additional financial support was granted from Godsejer Viktor 
Albert Goldschmidts Fond (Det Kongelige Danske Landhusholdningsselskab, Copenhagen, Denmark). Equipment was kindly provided by Nicolai Agger (Pharmalett, Kolding, Denmark) and Department of Food Science, University of Copenhagen (Denmark). In particular we thank Martin B. Thoefner (University of Copenhagen, Denmark) for ideas, inspiration, and discussions and Keith Baptiste (University of Copenhagen, Denmark) for linguistic support.

\section{REFERENCES}

Bancroft, J. D., and A. Stevens. 1996. Theory and Practice of Histological Techniques. 4th ed. Churchill Livingstone, Hong Kong, China.

Bergsten, C. 1994. Haemorrhages of the sole horn of dairy cows as a retrospective indicator of laminitis: An epidemiological study. Acta Vet. Scand. 35:55-66.

Bergsten, C., and C. Mulling. 2004. Some reflections on research on bovine laminitis-Aspects of clinical and fundamental research. Pages 53-60 in 13th International Symposium and 5th Conference on Lameness in Ruminants. Maribor, Slovenia. B. Zemljic, ed.

Capion, N., S. M. Thamsborg, and C. Enevoldsen. 2008. Prevalence of foot lesions in Danish Holstein cows. Vet. Rec. 163:80-85.

Chapinal, N. 2008. Automated detection of lameness in dairy through measures of weight distribution. Page 283 in 15th Symposium and 7th Conference on Lameness in Ruminants. Kuopio, Finland. Savonia University of Applied Sciences, Kuopio, Finland.

Cook, N. B. 2003. Prevalence of lameness among dairy cattle in Wisconsin as a function of housing type and stall surface. J. Am. Vet. Med. Assoc. 223:1324-1328.

Cook, N. B., K. V. Nordlund, and G. R. Oetzel. 2004. Environmental influences on claw horn lesions associated with laminitis and subacute ruminal acidosis in dairy cows. J. Dairy Sci. 87(E Suppl.):E36-E46.

Cramer, G., K. D. Lissemore, C. L. Guard, K. E. Leslie, and D. F. Kelton. 2008. Herd- and cow-level prevalence of foot lesions in Ontario dairy cattle. J. Dairy Sci. 91:3888-3895.

Cross, S. S. 1998. Grading and scoring in histopathology. Histopathology 33:99-106

Danscher, A. M., H. L. Enemark, P. H. Andersen, B. Aalbæk, and O. L. Nielsen. 2009b. Polysynovitis after oligofructose overload in dairy cattle. J. Comp. Pathol. doi:10.1016/j.jcpa.2009.09.001.

Danscher, A. M., J. M. D. Enemark, E. Telezhenko, N. Capion, C T. Ekstroem, and M. B. Thoefner. 2009a. Oligofructose overload induces lameness in cattle. J. Dairy Sci. 92:607-616.

Donovan, G. A., C. A. Risco, G. M. D. Temple, T. Q. Tran, and H. H. Van-Horn. 2004. Influence of transition diets on occurrence of subclinical laminitis in Holstein dairy cows. J. Dairy Sci. 87:7384.

Dowling, B. A., and A. J. Dart. 2005. Mechanical and functional properties of the equine superficial digital flexor tendon. Vet. J. 170:184-192

Furst, A. 1992. Makroskopische und mokroskopische anatomie der rinderklaue. Universität Zürich, Zürich, Switzerland.
Green, L. E., V. J. Hedges, Y. H. Schukken, R. W. Blowey, and A. J. Packington. 2002. The impact of clinical lameness on the milk yield of dairy cows. J. Dairy Sci. 85:2250-2256.

Knott, L., J. F. Tarlton, H. Craft, and A. J. F. Webster. 2007. Effects of housing, parturition and diet change on the biochemistry and biomechanics of the support structures of the hoof of dairy heifers. Vet. J. $174: 277-287$.

Lischer, C. J., P. Ossent, M. Raber, and H. Geyer. 2002. Suspensory structures and supporting tissues of the third phalanx of cows and their relevance to the development of typical sole ulcers (Rusterholz ulcers). Vet. Rec. 151:694-698.

Livesey, C. T., T. Harrington, A. M. Johnston, S. A. May, and J. A. Metcalf. 1998. The effect of diet and housing on the development of sole haemorrhages, white line haemorrhages and heel erosions in Holstein heifers. Anim. Sci. 67:9-16.

Maierl, J. 2004. The suspensory apparatus of the ruminant phlanxFunctional anatomy and biomechanics of the bovine hoof Tierarztliche Praxis Ausgabe Grosstiere Nutztiere 32:239-244.

Maierl, J., R. Bohmisch, M. Dickomeit, and H. G. Liebich. 2002. A method of biomechanical testing the suspensory apparatus of the third phalanx in cattle: A technical note. Anat. Histol. Embryol. $31: 321-325$

Mulling, C. K. W., and C. Lischer. 2002. New aspects on etiology and pathogenesis of laminitis in cattle. Pages 236-247 in XXII World Buiatrics Congress. Hannover, Germany. M. Kaske, H. Scholz, and M. Hölterschinken, ed Klinik für Rinderkrankheiten, Veterinary University, Hannover, Germany.

Nilsson, S. A. 1963. Clinical, morphological, and experimental studies of laminitis in cattle. Acta Vet. Scand. 4(Suppl. 1):7-304.

O'Callaghan, K. A., P. J. Cripps, D. Y. Downham, and R. D. Murray. 2003. Subjective and objective assessment of pain and discomfort due to lameness in dairy cattle. Anim. Welf. 12:605-610.

Obel, N. 1948. Studies on the histopathology of acute laminitis. Dissertation, The Royal Veterinary College, Uppsala, Sweden.

Peterse, D. J. 1979. Nutrition as a possible factor in the pathogenesis of ulcers of the sole of the feet of cattle. Tijdschr. Diergeneeskd. 104:966-970.

Sprecher, D. J., D. E. Hostetler, and J. B. Kaneene. 1997. A lameness scoring system that uses posture and gait to predict dairy cattle reproductive performance. Theriogenology 47:1179-1187.

Tarlton, J. F., D. E. Holah, K. M. Evans, S. Jones, G. R. Pearson, and A. J. F. Webster. 2002. Biomechanical and histopathological changes in the support structures of bovine hooves around the time of first calving. Vet. J. 163:196-204.

Thoefner, M. B., C. C. Pollitt, A. W. van Eps, G. J. Milinovich, D. J. Trott, O. Wattle, and P. H. Andersen. 2004. Acute bovine laminitis: A new induction model using alimentary oligofructose overload. J. Dairy Sci. 87:2932-2940.

Thoefner, M. B., O. Wattle, C. C. Pollitt, K. R. French, and S. S. Nielsen. 2005. Histopathology of oligofructose-induced acute laminitis in heifers. J. Dairy Sci. 88:2774-2782.

Webster, A. J. F. 2001. Effects of housing and two forage diets on the development of claw horn lesions in dairy cows at first calving and in first lactation. Vet. J. 162:56-65.

Webster, A.-J. F., L. Knott, and J. F. Tarlton. 2005. Understanding lameness in the dairy cow. Cattle Pract. 13:93-98. 